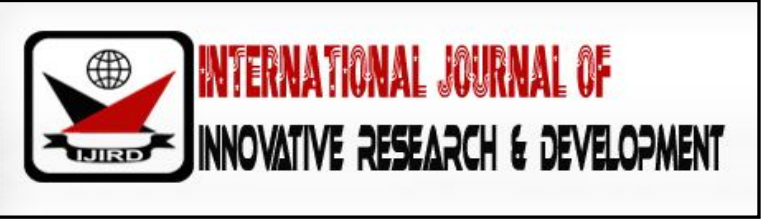

ISSN 2278 - 0211 (Online)

\title{
Influence of Composition Board of Directors, Board of Commissioners, and Audit Committees to Banking Financial Performance (Empirical Study on Banking Industry Listed in BEI 2011-2016)
}

\begin{tabular}{|c|}
\hline Apollo \\
Postgraduate Lecturer, Mercu Buana University, Indonesia \\
Mandalika \\
Postgraduate, Alumni of MercuBuana University, Indonesia \\
Said Djamaluddin \\
Postgraduate Lecturer, MercuBuana University, Indonesia
\end{tabular}

\section{Abstract:}

The purpose of this study is to examine the influence of the Composition of the Board of Directors, Board of Commissioners, and Audit Committee as independent variables on Return on Equity as the dependent variable. This type of research is classified as a causal study. The population in this study is a banking company listed on the Indonesia Stock Exchange in 2011-2016. The sample was determined based on the saturated sample, with the sample number of 21 companies. Data analysis technique used in this research is multiple regression analysis technique. The results of this study found that (1) the variables of the Board of Directors and Board of Commissioners have no significant effect on Return On Equity; (2) Audit Committee has a significant effect on Return On Equity.

Keywords: The composition of the board of directors, the composition of the board of directors, the composition of the audit committee, and the return on equity

\section{Background Issues}

The financial statements are often used as the basis for a company's performance appraisal. One type of financial statement that measures the success of a company's operations for a given period is the income statement.

Good Corporate Governance helps to create a conducive and accountable relationship among the elements of the company (Board of Commissioners, Board of Directors and shareholders) in order to improve the company's performance. In this paradigm, the Board of Commissioners is in a position to ensure that the management has actually worked in the interests of the company in accordance with the established strategy and to safeguard the interests of shareholders, namely to increase the economic value of the company. Likewise, the audit committee has a very important and strategic role in maintaining the credibility of the process of preparing financial statements as well as maintaining the creation of adequate corporate supervisory system and the implementation of Good Corporate Governance.

This study aims to examine the effect of corporate governance variables that have been adjusted to the business environment conditions in Indonesia on financial performance as measured by return on equity (ROE).

Based on the above background description, the authors are motivated to conduct further research under the title "The Influence of Composition of Board of Directors, Board of Commissioners, and Audit Committee on Financial Performance of Banking (Study on Banking Industry Registered on Indonesia Stock Exchange 2011-2016)" .

\subsection{Research Problems}

Based on the description on the previous background, then the formulation of the problem in this study are:

(1) The composition of the board of directors influence the financial performance (2) composition of the board of commissioners influence the financial performance (3)The Audit committee composition influence the financial performance 


\section{The Literature and Development of Hypotheses}

\subsection{Agency Theory}

The agency relations perspective is the foundation used to understand corporate governance. Jensen and Meckling stated that the agency relationship is a contract between the manager (agent) and the investor (principal). Conflicts of interest between owner and agent occur because the possibility of an agent does not always do in accordance with the interests of the principal, thus triggering agency costs. The emergence of earnings management can be explained by agency theory.

Jensen (1976) reveals As an agent, managers are morally responsible for optimizing the principal's profits and in return for compensation in accordance with the contract. Thus there are two distinct interests in the enterprise in which each party seeks to attain or maintain the desired level of prosperity. Eisenhardt (1989) states that agency theory uses three assumptions of human nature: (1) human beings are generally self-interested, (2) human beings have limited thinking about bo unded rationality, and (3) humans always avoid risk (risk averse). Based on the assumptions of human nature, managers as human beings will act opportunistic, namely prioritizing personal interests.

Watts \& Zimmerman, (1990) states financial statements as accounting numbers that are expected to minimize conflicts among interested parties.

\subsection{Good Corporate Governance}

Brown (2004) reveals that if the implementation of good corporate governance can be run effectively and efficiently, then the whole process of corporate activity will run well, so that things related to the performance of the company both the financial and non financial performance will also improve.

According to Newel \& Wilson (2002) theoretically, good corporate governance practices can increase corporate value, improve financial performance, reduce possible risks by the board with those decisions benefit themselves, and generally increase investor confidence

\subsubsection{Principles of Good Corporate Governance}

The Organization for Economic Cooperation and Development (OECD) offers principles that are key indicators of good corporate governance. These principles include: Fairness, Transparency, Accountability, and Responsibility.

Thomas (2006) reveals the four principles are important because the implementation of the principle of good corporate governance consistently proved to improve the quality of financial statements and also can be a barrier to performance engineering activities resulting in financial statements does not describe the fundamental value of the company.

Henry Campbell (2006) A fundamental truth or doctrine, as of law; a comprehensive rule or doctrine which furnishes a basis or origin for others; a settled rule of action, procedure, or legal determination. A truth proposition so clear that it cannot be proved or contradicted unless by a proposition which is still clearer. That which constitutes the essence of a body or its constituent parts. That which pertains theoretical part of a science.

\subsection{Financial Performance}

Return on equity (ROE) is used to measure the company's effectiveness in generating profit by utilizing its own equity. $\mathrm{ROE}$ is the ratio between profit after tax to total equity derived from ownership capital, unspecified profit and other reserves obtained by the company. ROE analysis is often translated as own capital rent ability. ROE means also a measure to assess how much the return rate of the capital itself invested in the business concerned is expressed as a percentage.

Investors are more expecting a high ROE than ROA because ROA is closely related to the debt of companies that contain debt costs. In accordance with the Duppont method, ROA still contains leverage multiplier. In an improved economic situation, the company is expected to use more debt (with interest expense), because it can increase its own return on equity, because the additional profit earned is greater than the additional interest cost. Conversely, if economic conditions worsen, generally companies that have large third-party capital will experience a decrease in ROE, so that the existence of own capital is better than debt financing. In the worsening economic conditions, the additional interest expense will be greater than the additional profit earned. The higher the company's profit after tax then the higher the ROE. The amount of corporate profits is influenced by the ability of companies to generate profits through sales activities are reflected through net profit margin and corporate sales activities by utilizing the total assets are reflected through total asset turnover.

\subsection{Board of Directors}

In UU No.40 Tahun 2007 about Perseroan Terbatas, the Board of Directors is a competent company organ and fully responsible for the management of the company for the benefit of the company in accordance with the intent and purpose of the company and representing the company, both inside and outside the court in accordance with the articles of association. In the context of monitoring the bank's internal control, the board of directors has the responsibility of establishing policies and strategies that have been approved by the board of commissioners, maintaining an organizational structure, ensuring that effective delegation of powers is supported by consistent application of accountability and monitoring the adequacy and effectiveness of the system Internal control. 


\subsection{Board of Commissioners}

There are two different management systems derived from two different legal systems (FCGI, 2002) that distinguish the oversight mechanisms conducted by the Board of Commissioners (1) One Level System or One Tier System, (2) Two Level System or Two Tiers System.

\subsection{Audit Committee}

In accordance with PBI No.8 / 14 / PBI / 2006 dated 5 October 2006 and Bank Indonesia Circular Letter No.15/ 15/ DPNP dated 29 April 2013 regarding the implementation of Good Corporate Governance for commercial banks. With the increasing complexity of duties and functions of the board of commissioners in conducting supervision of the bank then required audit committee established by and responsible to the board of commissioners in helping carry out its duties and functions. In general, the Indonesian Corporate Governance Forum (2001) explains that the audit committee has responsibilities in three areas: (1) financial reporting, (2) corporate governance, and (3) supervision of the company.

\subsection{Development of Hypotheses}

- Effect of Board of Directors' Composition on Financial Performance

- H1: The composition of the board of directors affect the Financial Performance

- The Effect of Board of Commissioners Composition on Financial Performance

- H2: The composition of the board of commissioners influences the Financial Performance

- Effect of Audit Committee Composition on Financial Performance

- H3: The composition of audit committee has an effect on to Financial Performance

\section{Research Methods}

\subsection{Population and Sample}

The criteria specified in the sampling process are as the following:

- Banks that report audited financial statements from 2011-2016 and publish financial statements for the year ended December 31.

- Banks that list during the observation period.

\subsection{Empirical Model}

This study uses the empirical model as follows:

$\mathrm{ROE}=\alpha+\beta_{1} \mathrm{KDD}+\beta_{2} \mathrm{KDK}+\beta_{3} \mathrm{KKA}+\varepsilon$

Information:

ROE: Return on Equity

$\alpha \quad$ : Constants

$\beta_{1,2,3} \quad$ : Regression coefficient

KDD : Composition of the Board of Directors

KDK : Composition of the Board of Commissioners

KKA : Composition of the Audit Committee

$\varepsilon$ : Residual Variable (Error level)

\subsection{Data Analysis Techniques}

Methods of data analysis in this study using multiple regression analysis and data processing using computer SPSS version 23. Before doing data analysis and hypothesis test first presented descriptive statistics of each independent variable and dependent variable

\section{Results and Discussion}

\subsection{Correlations}

\begin{tabular}{|c|c|c|c|c|c|}
\hline \multicolumn{2}{|c|}{} & KDD & KDK & KKA & ROE \\
\hline \multirow{3}{*}{ KDD } & Pearson Correlation & 1 & $\begin{array}{c}.645 \\
* *\end{array}$ & $\begin{array}{c}.425^{*} \\
{ }^{*}\end{array}$ & $.346^{* *}$ \\
\cline { 2 - 6 } & Sig. (2-tailed) & & .000 & .000 & .000 \\
\cline { 2 - 6 } & $\mathrm{N}$ & 126 & 126 & 126 & 126 \\
\hline \multirow{3}{*}{ KDK } & Pearson Correlation & $.645^{* *}$ & 1 & $\begin{array}{c}.545^{*} \\
*\end{array}$ & $.382^{* *}$ \\
\cline { 2 - 6 } & Sig. (2-tailed) & .000 & & .000 & .000 \\
\cline { 2 - 6 } & $\mathrm{N}$ & 126 & 126 & 126 & 126 \\
\hline
\end{tabular}




\begin{tabular}{|c|c|c|c|c|c|}
\hline & & KDD & KDK & KKA & ROE \\
\hline \multirow{3}{*}{ KKA } & Pearson Correlation & $.425^{* *}$ & $\begin{array}{c}.545 \\
* *\end{array}$ & 1 & $.456^{* *}$ \\
\cline { 2 - 6 } & Sig. (2-tailed) & .000 & .000 & & .000 \\
\cline { 2 - 6 } & $\mathrm{N}$ & 126 & 126 & 126 & 126 \\
\hline \multirow{3}{*}{ ROE } & Pearson Correlation & $.346^{* *}$ & $\begin{array}{c}.382 \\
* *\end{array}$ & $\begin{array}{c}.456^{*} \\
*\end{array}$ & 1 \\
\cline { 2 - 6 } & Sig. (2-tailed) & .000 & .000 & .000 & \\
\cline { 2 - 6 } & $\mathrm{N}$ & 126 & 126 & 126 & 126 \\
\hline
\end{tabular}

Table 4.1: Pearson Test Results

**. Correlation Is Significant at the 0.01 Level (2-Tailed)

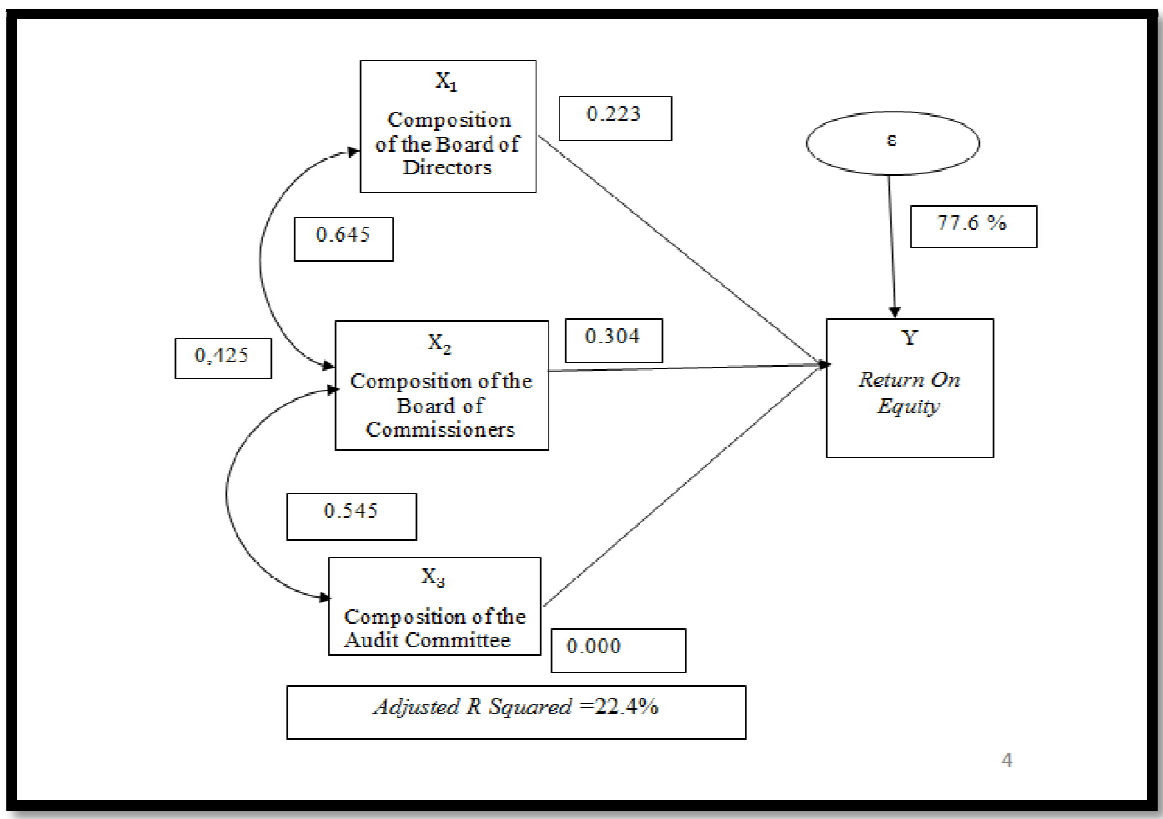

Picture 4.1: Results of the Research Model

From the table and research module above, we get the regression equation as follows:

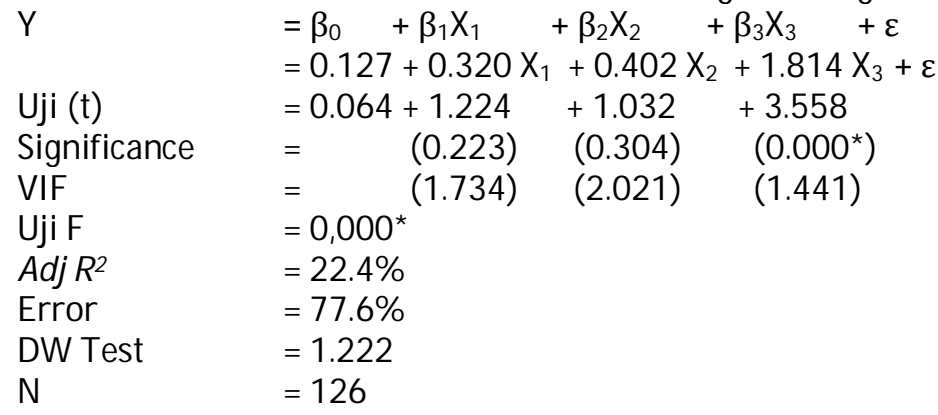

\section{Information :}

$(*)$

$\mathrm{Y}$

$\mathrm{X}_{1}$

$\mathrm{X}_{2}$

$\mathrm{X}_{3}$

$\beta_{0}$

$\beta_{1}, \beta_{2}, \beta_{3}$

$\varepsilon$

$\mathrm{N}$

Alpha
$=$ Signification

$=$ Return On Equity

$=$ Composition of the board of directors

$=$ Composition of the Board of Commissioners

$=$ Composition of the audit committee

$=$ Constants

$=$ The regression coefficients of each variable

=Eror Term

$=$ Total Sample 126 ( 21 samples in 6 years)

$=0,05$ 


\subsection{Discussion}

Test results in this study are:

- Effect of Board of Directors' Composition on Return On Equity

- KDD regression coefficient value of 0.320 and $t$ value of KDD variable counted 1.240 positive on the regression coefficient with significance level of 0.223 . Significance value $0.223>0.05$, this means that the composition of the board of directors has a positive influence is not significant to Return On Equity. Thus the first hypothesis states that the composition of the board of directors has no effect on Return On Equity.

- The Effect of Composition of Board of Commissioners on Return On Equity

- KDK regression coefficient value of 0.402 and t value of KDK variable of 1.032 positive on the regression coefficient with a significance level of 0.304. Significant value $0.304>0.05$, this means that the composition of the board of commissioners has an insignificant positive effect on Return On Equity. Thus the second hypothesis states that the composition of the board of commissioners has no effect on financial performance.

- Effect of Audit Committee Composition on Return On Equity

- KKA regression coefficient value is 1.814 and $t$ value of KKA variable is 3.558 positive at regression coefficient with significance level equal to 0.000 . Signification value $0.000 \varangle 0.05$, this means that the composition of the audit committee has a significant positive effect on Return On Equity. Thus the third hypothesis states that the size of the audit committee affect the Return On Equity.

\section{Conclusions, Limitations, and Practical Contributions}

The conclusions that can be taken in this research are as follows:

- The composition of the board of directors has no effect on financial performance.

- The composition of the board of commissioners has no effect on financial performance.

- The composition of the audit committee affects the financial performance.

Limitations in this study is the authors of independent variables are only able to explain $22.4 \%$ of the dependent variable, it shows that other variables that are not used in this study have a greater influence on the financial performance of banks.

The practical contribution of this research is the future policy contribution for the company to disclose more detailed information about the aspects of Good Corporate Governance (GCG).

\section{References}

i. Adestian Y. (2015). Pengaruh Dewan Komisaris, Dewan direksi, Dewan Komisaris Independen, Komite Audit pada Kinerja Perusahaan Perbankan yang Listing di BEI pada tahun 2012-2014. Skripsi Fakultas Ekonomi dan Bisnis Universitas Dian Nuswantoro

ii. Alijoyo, Antonius., Elmar Bouma., TB M Nazmudin Sutawinangun, dan M Doddy Kusadrianto, 2004, "Review of Corporate Governance in Asia: Corporate Governance in Indonesia", Forum for Corporate Governance in Indonesia.

iii. Boediono, 2005, "Kualitas Laba: Pengaruh Mekanisme Corporate Governance dan Dampak Manajemen Laba", Simposium Nasional Akuntansi VIII, Solo.

iv. Brown, Lawrence, and J.,Caylor,"Corporate Governance and Firm Performance”, Boston Accounting Research Colloquium 15th, Desember 2004

v. Cornett M. M, J. Marcuss, Saunders dan Tehranian H, 2006, Earnings Management, Corporate Governance, and True Financial Performance, http:/ / papers.ssrn.com/

vi. Darmawati, Deni, Khomsiyah, dan Rika Gelar Rahayu, 2004, "Hubungan Corporate Governance dan Kinerja Perusahaan", Simposium Nasional Akuntansi VII, Denpasar

vii. Dariri, Mas Ahmad. “ Good Corporate Governance Konsep dan penerapannya dalam konteks Indonesia”, Jakarta: Ray Indonesia, 2005.

viii. Darwis, Herman. 2009. Corporate Governanve terhadap kinerja perusahaan. Jurnal Keuangan dan Perbankan, vol 13 No 3, sepember 2009, hal 418-430.

ix. Devano Sony dan Sii kurnia rahayu, "Perpajakan: Konsep, Teori, dan Isu”, cetakan Pertama, Jakarta: 2006

x. Efendi, Muh Arief. "The Power of Good Corporate Governance : Teori dan Implementasi”, Jakarta : Salemba Empat, 2009

xi. Fama, E.F. and Jensen, MC, 1983, "Separation of Ownership and Control" Journal of law and Economics 26.pp.301325

xii. Jensen, Michael C. dan W.H. Meckling.1976."Theory of The Firm: ManagerialBehavior,Agency Cost and Ownership Structure", Journal of Financial Economics. 3.

xiii. Khaihatu, Thomas S. "Good Corporate Governance dan Penerapanna di Indonesia", Jurnal Managemen dan Kewirausahaan vol 8 no 1: 1-9 Surabaya : 2006

xiv. [14]Kieso, Donald E and Jerry J Weygandt, 1995, Intermediate Accounting, Fourth Edition, John Willey and Sons: New York. 
xv. Kresnohadi, Ariyoto. "Good Corporate Governance dan Konsep Penegakannya di BUMN dan lingkungan usaha”, Majalah usahawan No 10 Tahun XXIX, 2000

xvi. Lestari, Prastya Puji dan cahyonowati Nur. 2013. Pengaruh Good Corporate Governance terhadap Kinerja perusahaan. e- Journal Accounting Universitas Diponegoro, Semarang. Vol 2, No 4, Hal 1-13.

xvii. Lestari, D.E. (2010). Pengaruh Good Corporate Governance terhadap Kinerja Keuangan. Skripsi Fakultas Ekonom Diponegoro, semarang.

xviii. Maksum,Azhar. "Tinjauan atas Good Corporate Governance di Indonesia"' Gelanggang mahasiswa, Kampus universitas Sumatera Utara, Medan : 17 Desember 2005

xix. Midiastuty, Pratana P., dan Mas'ud Machfoedz, 2003, Analisis Hubungan Mekanisme Corporate Governance dan Indikasi Manajemen Laba, pada Simposium Nasional Akuntansi 6 Surabaya tanggal 16-17 Oktober 2003

xx. Solomon, J., and Solomon, A. 2004. “Corporate Governance and Accountability”,John Wiley \& Sons, Ltd.

xxi. Sudarmayanti. 2007."Good Governance (Kepemerintahan yang Baik) dan Good CorporateGovernance (Tata Kelola Perusahaan yang Baik)", Bandung: CV. Mandar Maju, bagian ketiga

xxii. Widiawati Sri H. (2011). Pengaruh Corporate Governance terhadap Kinerja Keuangan. Tesis Fakultas Ekonomi Sebelas Maret, surakarta (Tidak Dipublikasikan)

xxiii. Widagdo, Dominikus Octavianto Kresno dan Chariri Anis. 2004. Pengaruh Good Corporate Governance terhadap Kinerja Perusahaan. E- Journal Acounting Universitas Diponegoro Semarang. Vol 3, No. 3, Hal: 1.

xxiv. Wulandari, Ndaruningpuri. 2006. Pengaruh Indikator Mekanisme Corporate Governance terhadap Kinerja Perusahaan publik di Indonesia. Fokus Ekonomi, vol 1, no 2. Desember 2006:120-136.

xxv. Veronica, Sylvia, dan Siddharta Utama, 2005, Pengaruh Struktur Kepemilikan, Ukuran Perusahaan, dan Praktek Corporate Governance terhadap Pengelolaan Laba (Earnings Management), Simposium Nasional Akuntansi 8, Solo, Tanggal 15 - 16 September 2005. 